\title{
3. Witchcraft, Sorcery, Violence: Matrilineal and Decolonial Reflections
}

\author{
Salmah Eva-Lina Lawrence
}

\section{Introduction}

In this chapter, a version of which was presented at the June 2013 conference Sorcery- and Witchcraft-Related Killings in Melanesia: Culture, Law, and Human Rights Perspectives, I discuss witchcraft and sorcery in the Milne Bay context, specific to communities in and around Alotau and the surrounding bay area, and some of the islands in the China Strait. I am also concerned with the law and human rights perspectives surrounding much of the discussion of the recent sorcery- and witchcraft-related violence in Papua New Guinea (PNG). I make an argument for decolonising both the discourse and the formulation and implementation of policy. I conclude with what is so obvious to us Papua New Guineans that it is taken for granted. And this fact is, that for most Papua New Guineans, the choice is not, and never will be, either culture or modernisation. It is both culture and modernisation. Policy formulation, therefore, has to be undertaken within this context.

It is refreshing and encouraging to see from the spread of papers in this book that many Melanesians have been given space to articulate their views. It has been more often the case that we are lectured about being basket cases in an 'arc of instability'. From the late 1990s, the 'arc of instability' has been used to describe a range of countries from East Timor to Fiji, encompassing PNG and Solomon Islands (Rumley 2006). These states are deemed to fall short of the liberal democratic model, lacking robust institutions, good governance and security for their populations. However, as Dobell (2007) argues, the term may have use in Canberra but has no value as an analytical tool and probably has more to do with what Rosewarne (1997:97) called 'Australia's pretensions as a superpower in the region'.

The chapters on PNG in this volume demonstrate an array of belief systems and ways in which accusers and perpetrators of violence relate to victims. However, the overall theme is that witchcraft and sorcery invariably lead to physical violence. Some questions are also raised on the different types of witchcraft and sorcery. In this paper, I challenge the notions that witchcraft and sorcery invariably lead to violence, that there is only one type of witchcraft and sorcery, 
and that what is labelled witchcraft and sorcery in English is entirely superstitious nonsense. I heard too from fellow Papua New Guineans at the June conference on the importance of our cultures to us and I also heard from them that a defence of culture is not a defence of violence, themes that I also touch upon.

This chapter is partially a reflection shaped by my lived experience as a woman from a matrilineal culture in PNG, a culture in which witchcraft and sorcery remain significant despite early Christianisation. A reflection that is shaped by a mutual embeddedness, me in my culture and my culture in me, an embeddedness that is not weakened by my Western education, nor by a career in senior management for a global business advisory firm in London and New York, nor by working for the United Nations in international development. Here I share thoughts about my culture and its traditions of matriliny and also about witchcraft and sorcery, and how these have shaped egalitarian gender relations in much of Milne Bay Province.

Despite early Christianisation, belief and practice of witchcraft continues to be prevalent in this primarily matrilineal province. Even outside the province, the flying witches of Milne Bay are legendary and Milne Bay itself has been described anecdotally as the witchcraft centre of PNG. In contrast to other chapters from PNG in this volume which speak of witchcraft and sorcery accusations that generate brutal violence on the accused, violence against women is much less in this province where witchcraft is highly articulated, and it is said to empower and contribute to the status of Milne Bay women. Addressing this paradox is a key theme of this chapter.

I will start with a discussion of matriliny and gender relations in Milne Bay, as these form a framework for understanding why violence is largely absent there. Then I will present some observations on witchcraft and sorcery as it unfolds in Milne Bay. I next present my arguments for decolonising the discourse and then I share some ideas about policy and practical responses before I finish with some reflections on culture.

\section{Matriliny and gender relations in Milne Bay}

Matriliny is often defined as a rule of descent and inheritance, but in Milne Bay it provides a basis for an identity interwoven with land and kinship relationships (Demian 2007; Lepowsky 1993). For the people of Milne Bay, matriliny is both a descent system and a way of organising social relations. The problem with translation into English is that one loses the depth of meaning inherent in our own languages because an equivalent value and practice does not exist in Anglocentric social systems. Matriliny is the closest term that only partially describes the way kinship is central to gender relations in Milne Bay. 
Social relations shaped by matriliny demonstrate a predisposition towards egalitarian gender relations, or gender complementarity. ${ }^{1}$ Indeed, since the 1870s, Europeans making their way through precolonial eastern Papua have noted the relatively high status of women (Wetherell and Abel 1998).

That gendered roles exist throughout Milne Bay is not contested, but I have suggested that egalitarianism and acceptance of difference is the basis of gender relations. When compared to United Nations' measures of equality, Milne Bay people in their traditional environments score very highly (Lawrence 2013). Milne Bay women exercise a great deal of autonomy. They have physical mobility, a key factor in power relations and they continue to travel, and to have freedom in marriage partners and in divorce. Abhorrence of physical violence and a respect for autonomy produced an environment in some of the islands where rape was unheard of (Lepowsky 1993). Women have access to economic power as they have access to land and are able to accumulate wealth (Demian 2007). (Milne Bay people traditionally did not own land; however, custodianship confers rights to determine or control usage. $)^{2}$ Women practised traditional contraception, spaced their children and enjoyed premarital sexual freedom (Lepani 2012). In other words, women control their own bodies. Across Milne Bay, male and female children are equally desired; there is recognition that matrilineages cannot be sustained without both males and females (Demian 2000). Women's influence included not only determining when to go to war, they also participated in generating peace through preventing war and bloodshed and they have not relinquished this power (Lepowsky 1993). This form of restorative justice, and a key feature of Milne Bay women's agency, continues to be initiated in the present day - women will remove their skirts in situations of conflict. This method is used in the islands of the Bwanabwana district and even in the urban environment of Alotau. ${ }^{3}$

Lest I be misconstrued as suggesting that Milne Bay people are singular social beings, let me be clear that violence did and does exist. I am here preempting charges of exceptionalism, especially as I have elsewhere positioned Milne Bay gender relations as indigenous best practice. My intent is not to create separateness from other Papua New Guineans. It is to demonstrate that the mainstream development model, in which the exceptionalism of European culture is implicit, and which thus seeks to bring gender equality to supposedly lesser developed peoples, is culturally and racially constructed because it

\footnotetext{
1 Gender as stipulated within Western feminism is not universal. This is recognised, particularly by Third Wave feminism, contemporary African-American, Latin American, African and other majority world feminists, who have argued that in many parts of the world gender roles are complementary. See, for example, OyĕwÙmí (1997). Others, such as anthropologist Peggy Sanday (1981), have also explored non-adversarial gender relations.

2 Personal communication in May 2013 with Anne Dickson-Waiko clarified this point.

3 This method has been utilised in contemporary times by some women in my extended family.
} 
denies that these lesser developed peoples, of whom I am one, could possibly have moral frameworks that promote women's status. The challenge for other Papua New Guineans is to identify similar models in their own cultures that correspond to a rights and responsibilities framework and the challenge for all of us is to continue to live as a pluralist nation-state. Let me also be clear that best practice for me does not imply a single universal model. For the people of Milne Bay, matriliny and gender relations are a practice that has contributed, and continues to contribute, to our survival. It will remain relevant for as long as it is useful for the people of Milne Bay. That it is best practice in Milne Bay does not automatically position it so for all of PNG.

Violence in Milne Bay includes precolonisation warfare, which was often triggered by witchcraft and sorcery allegations, and was rife among some communities, and domestic, family and sexual violence does exist (Macintyre 1983). Interaction through relatively early European contact has brought changes that include new structures for managing relationships, some of which I will demonstrate later (Macintyre 1995). Nonetheless, Milne Bay people continue to strongly assert their own identity and the social basis for egalitarian gender relations remains strong (Kaniku 1981). Some have also suggested that women's use of witchcraft is a factor in these egalitarian relations (Macintyre 1987).

\section{Witchcraft and sorcery in Milne Bay}

Witchcraft and sorcery in Milne Bay are part of the fabric of daily life in the sense that they are omnipresent. Few practitioners openly admit their involvement, perhaps due to the legacy of negative connotations conferred by Christianity and colonisation, and if they do, they are reluctant to divulge knowledge. But I have also met two women who have been entirely transparent about being practitioners. I will use the Suau language words alawai and balau, which approximate to witch and sorcerer, and operate as nouns and verbs. I say approximate because witch/witchcraft and sorcerer/sorcery have overwhelmingly negative connotations in European cultures but alawai and balau do not necessarily convey negative meanings in Milne Bay.

An alawai is usually, but not always, female. The activity attributed of alawai is attributed to many women, who in this matrilineal culture are said to pass their alawai skills on to their daughters. A balau is usually male, although it is known for men to pass their skills to daughters in the absence of sons. Both alawai and balau are said to fly; that is, they can leave their bodies and travel through space but not through time. Both exercise an array of functions that 
might include garden magic and protective magic. ${ }^{4}$ Alawai cannibalise the dead; like balau they can kill the living. But they can also heal; their knowledge of herbs being essential to pregnancy, childbirth and contraception among other things. There is also a third category of persons who protect. This person does not seem to have a different designation in the Suau language; one of the men I interviewed, who defined himself as providing protection through sorcery, refused to be identified as either alawai or balau, nor was he able to offer a Suau word to designate his function. This is possibly because Suau, our common language, was not his native language. In other parts of Milne Bay, however, this third category of person is designated differently. ${ }^{5}$

Masigili, which translates as dark/darkness is also associated with alawai and balau, regardless of whether they heal or harm. There seems to be a reticence in attributing alawai or balau to named individuals, whereas one can imply their involvement by the less direct term masigili. Nonetheless, alawai are often associated with brightness, appearing at night in forms that emanate light. I suspect that missionaries who positioned their teachings as mala, meaning light, intended to create the binary of masigili/mala, darkness/light. Alawai and balau do not always need a physical medium like food by which to enter a person's body. Much fear is generated by the belief that they can affect a person by gaze, by touch, and through the non-physical body they use to fly. Illness and death, especially among young people, continues to be attributed frequently to alawai or balau, notwithstanding the early Christianisation of this part of PNG. ${ }^{6}$

In the course of researching this paper, I uncovered only one recent instance of what was classified by the courts as a witchcraft-related killing in Milne Bay Province. ${ }^{7}$ In 2007, Sedoki Lota and Fred Abenko, both from Normanby Island, were charged with the murder of Marcia Kedarossi, whom they alleged killed their parents through witchcraft. According to court documents the accused were offered payment of cash and traditional money and wealth by a man from a neighbouring village, and this led to the attack on, and decapitation of, Marcia Kedarossi. ${ }^{8}$ Witchcraft accusations aside, the court determined that this was clearly a premeditated murder for which the accused were to be paid by a third party and the accused received the death sentence.

\footnotetext{
4 Personal communication in May 2013 with Anne Dickson-Waiko, herself from Milne Bay, confirms that for communities in and around Ahioma, the range of practices includes gardening magic, healing and protective magic. See also Lepani (2012) on these practices in the Trobriand Islands.

5 See also Lepani (2012).

6 Following exploratory forays in the preceding decade, the London Missionary Society, the Anglicans and the Methodists all established missions on the mainland and islands of Milne Bay in 1891 (Wetherell 2012).

7 I spent one month in Milne Bay Province where I interviewed four practitioners and conducted two focus groups, at Alotau and at Kwato, about alawai and balau persons and activities. I also interviewed one policeman, three village councillors, and one female community worker.

8 State v. Sedoki Lota \& Fred Abenko (Unreported, N3183, 2007, Sevua J).
} 
Why, then, are cases of physical violence towards practitioners of witchcraft and sorcery less frequent in Milne Bay Province even when the practices are seen to be the underlying cause of disease and deaths? My earlier discussion on matriliny and gender has highlighted a sociality predisposed to gender egalitarianism, which unfolds as an aversion to physical violence, and includes a practice of restorative justice traditionally initiated by women through the removal of their skirts to protect, and to prevent war and bloodshed (Kaniku 1981). In the present, and on a practical level, conflict, witchcraft-related or otherwise, is managed through community mediation. Besides accused, accuser, and their kin, a mediation can involve the village councillor and the pastor, actors introduced through contact with Europeans.

I have been an observer at one such mediation which involved an extended family group that could be regarded as middle class: members are university educated and/or have professional qualifications; many are urban based; and they are strongly associated with the church and identify as Christian. After a spate of deaths of young to middle-aged people in this group, and some serious illnesses, an older woman was accused of causing this misfortune through witchcraft. She vigorously denied all accusations, going to the extent of shaming herself by removing her clothing during the community mediation. This woman was raised in a mission not a village. She and her husband, who was already deceased at the time of the accusations, were both professionals. The woman's nudity was, however, insufficient to quell the animosity and accusations directed at her. Physical violence was threated on her person as a future quid pro quo. But no physical violence was enacted on the day and has not been enacted in the intervening three years. Is this because this extended kinship group has a high degree of Western education, is it because they are Christianised, modernised? I cannot be certain but I speculate that as a female elder with significant control over kin and land, coupled with her extremely domineering personality, the accusation of witchcraft was a method by which the family group articulated latent hostilities which, once brought into the open, allowed members to get on with their lives. ${ }^{9}$

9 According to Patterson (1974), theories of sorcery and witchcraft can be broadly classified as anthropological or psychological, notwithstanding the disciplinary overlap. Where the latter tend towards the causal, anthropology orients to the functional/structural and causal. Social control is one such functional theory - those who are marginal or non-conformist are often foci for hostility and scapegoats of accusations. In this intra-group scenario, as data from Africa demonstrate, accuser and accused are known to each other. But evidence suggests this does not hold universally - the degree of hostility/strain/tension is not an accurate gauge of accusations and, Patterson highlights, is particularly problematic in the context of Melanesian data where peculiarities exist vis-à-vis whether the accusation is related to an illness or to a death, and whether it is intra- or inter-group. Nonetheless, in my case study, in which illness and death are coeval, the woman accused, a female elder with significant influence, is not marginal, but her controlling and domineering personality might be said to be non-conformist in an egalitarian society. 
Drawing on consultations I had with a policeman, several village councillors, and a female community worker, the same kind of mediation at the village level is often successful in diffusing the potential for physical violence. One of the councillors with whom I spoke claimed the bulk of his time was spent in such mediations. Enabling participants to air their grievances allows for hostilities to be dispersed and thus, in parts of Milne Bay, this appears to mitigate the tendency to physical violence. However, I must stress that mediations are not public forums; there is no blatant naming and shaming, and public records are not made. Mediations remain private matters among the kinship groups involved.

My intention in using this particular case study is to demonstrate that Westernisation does not lead to relinquishing traditional ontologies and epistemologies. Indeed, the Eurocentric premise that science would eventually trump religion and magic continues to be proven erroneous with the rise of religious fundamentalism in the United States and elsewhere, and the continuing beliefs in, and practice of, magic including Wicca and Paganism in the Anglophone West. Although science has been positioned as that which makes European knowledge singular, Tambiah (1990) and Nader (1996a) argue that this categorisation is but another social construction essentialising the hegemon's superiority over those who utilise magic and religion. Since the placement of Western science as superior is a socially constructed rather than universal truth, it is, therefore, unsurprising that other ontologies and epistemologies, such as those of the people of Milne Bay, indeed of PNG, continue to thrive.

Why, then, in the one place in PNG where witchcraft is articulated in so much depth is there so little violence against women, or cases of violent witchcraftrelated accusations and killings? There is a historical and cultural basis for the reduced levels of violence against women. In addition, a different trajectory to modernisation, which included relatively early exposure to introduced institutions of rule of law and church and new forms of managing conflict, has undoubtedly also had an impact. ${ }^{10}$ This raises other questions not addressed by this chapter, such as how do different cultures respond to the modernising project and the experiences of modernity? How are other places in PNG with different gender dynamics and different experiences of modernity responding to the West's model of development? Analysing these distinctions may provide insights into why accusations of witchcraft or sorcery have generated horrific violence in some parts of PNG but not in other parts, such as Milne Bay.

10 In 1884, prevailing geopolitics led to the annexation of the south-eastern portion of the island of New Guinea to form British New Guinea, which in 1905 became the Territory of Papua (Murray 1912). Missionaries had been active in Milne Bay since 1847, but it was from 1891 that major bases were established on the mainland and in the islands of Milne Bay by the London Missionary Society, the Anglicans and the Methodists (Wetherell and Abel 1998; see also Wetherell 2012). 
Talking it Through

\section{Which witchcraft? Decolonising the discourse}

Decoloniality, like the postcolonial, challenges a Eurocentric view of the world. Where it differs is a focus on scholars and thinkers from the majority world, an insistence that social and economic development is not a linear progression, and a commitment to pluralism. ${ }^{11}$ For me, the activism component of decoloniality unfolds through an emphasis on first looking within one's own culture for frameworks that correspond to, for example, human rights norms, then building on these frameworks as a means to bring about sustainable change.

I now turn to my reflections on the discourse of witchcraft and sorcery as it relates to PNG. When framed in relation to Christianity, witchcraft and sorcery assume negative connotations. Even in Patterson's (1974) pioneering efforts to classify Melanesian sorcery and witchcraft, in which she acknowledges that translation into English is problematic, she nevertheless opts to use a definition that is entirely negative, situated through its capacity to inflict harm. She qualifies that attending to this nuance is immaterial for the analysis she is undertaking, which is 'to explain the consequences these beliefs and the practices connected with them have for interpersonal and intergroup relations and for the individual ... [and] to determine the reasons for the differential stress placed on certain aspects of the phenomena in Melanesian societies' (Patterson 1974:140). Nonetheless, the oversimplification favouring a Eurocentric bias continues to inform many discussions of witchcraft and sorcery in Melanesia. Patterson (1974) does go on to acknowledge the different types of Melanesian magic and, in fact, makes reference to garden magic and sea magic, which are creative, productive and protective, not harmful. More recently, Lepani (2012) has provided a balanced presentation of the different applications of magic and its relationship to individual agency. It is clear that what is called magic is not always the malign force it is made out to be.

So which witchcraft are we talking about in this volume? My discussion has demonstrated that there are at least three types of practice in Milne Bay: harming, protecting and healing. In particular, the healing component has promoted gender egalitarianism as it has allowed women to have control over their bodies through regulating their fertility among other things. These bodies of knowledge, which are often dismissed in the West as being magical and therefore irrational, in fact constitute what UNESCO (2006) recognises as key resources that communities can utilise to combat destabilisation and marginalisation resulting from modernisation and globalisation. UNESCO (2005) protects these knowledges through conventions such as the Protection and

11 For more information on the Decolonial School see the special issue of Cultural Studies, Volume 21, Issue 2-3, 2007, Routledge. 
Promotion of the Diversity of Cultural Expressions. Furthermore, in Milne Bay it is recognised that this knowledge constitutes aspects of a person's wealth. Indeed, women who practise these forms of knowledge are said to be sibasiba, or wise, so it is unsurprising that witchcraft contributes to the esteem given to women in Milne Bay. ${ }^{12}$

What is this knowledge exactly? It is knowledge of psychology — understanding and, at times, manipulating human fears, desires and weaknesses. It is knowledge of the environment and ecology — including knowing how to sustain oneself from the land and sea, indeed how to navigate by reading the environment. ${ }^{13}$ It is knowledge of the body and of medicine - knowing what vines to use to set broken bones and what plants to treat dengue fever or aid childbirth. ${ }^{14}$ There is now a wealth of evidence that demonstrates how indigenous peoples the world over have highly developed knowledges of their environments in pharmaceutics, botany, navigation, and resource and food management, knowledge which Western science is benefiting from (Nader 1996a). Indeed, the ability to observe, test and validate to create knowledge is not unique to science (Nader 1996a). ${ }^{15}$ It is therefore, extremely problematic that magic or witchcraft and sorcery continue to be used to classify many different types of indigenous knowledges.

Tambiah's (1990) seminal work Magic, Science, Religion, and the Scope of Rationality draws on diverse disciplines to demonstrate that given its cultural construction, science is no more and no less rational than other cultural constructs such as magic and religion and that, ironically, its roots can be found in magic and religion. Nader (1996a), drawing on Tambiah, highlights how anthropologists from Edward Tylor, James Frazer and Bronislaw Malinowski are implicated in the construction of hierarchies essentialising the superiority of European science over reliance on magic and religion. So ingrained have these ideas become that

12 Anne Dickson-Waiko, personal communication May 2013, helped illuminate this point.

13 Over the course of my lifetime I have observed how people from Milne Bay plan and undertake activities for their livelihoods. Out in the islands (Kwato, Logeia) few people are employed in regular cash-generating employment. The source of food is still largely subsistence gardening and fishing. Ensuring a sufficient harvest to sustain the household requires knowledge that is not apparent to those of us whose provisions come from a supermarket. Likewise, navigating watercraft without the aid of machines means observing and knowing about winds, tides, stars and planetary positions, and a host of details such as the feel of the waves lapping at the sides of the craft. I know of many young men, and increasingly young women, from islands in the Bwanabwana district of Milne Bay, who possibly because of early exposure to such knowledge, are finding employment in the international maritime industry.

14 A man who lives at Divinai village demonstrated to me knowledge he had acquired from his grandfather regarding which vines were the most effective to set broken bones. Diseases such as malaria and dengue have obviously been present since before first contact with Europeans, and have been treated variously. Some of the remedies shared with me are similar to those in folk medicine in Thailand and Malaysia, according to friends from those countries.

15 Of this Eurocentric knowledge production, Nader (1996b:2) says ‘[a] style favoured by contrast includes some things, excludes others, and creates hierarchies privileging one form of knowledge over another ... Contrast also tends to fix a positional superiority in the mind of the categorizer — the notion that one is superior by virtue of being in a position to create the categories'. 
they continue to be used to justify interventions in the name of developing socalled 'primitive' peoples. While many are the critiques of magic and religion, scant in popular discourse are those that challenge the construction and ideology of science, natural and social, including those of the rule of Western law and human rights. These are ideologies that contribute to the construction of entire peoples as lacking, whether economically, jurisprudentially, and/or morally, and thus provide the basis for development interventions. ${ }^{16}$ Is it not, however, a form of fundamentalism, this extremist insistence that Western knowledge and concepts are the only valid epistemologies and ontologies for the entirety of humanity?

To decolonise the discourse is first to frame it from the subaltern side of the colonial divide. Furthermore, as Epeli Hau' ofa (1994:156-7) reminds us, '[o]nly when we focus on what ordinary people are actually doing, rather than on what they should be doing, can we see the broader picture of reality'. When one looks beyond media headlines into the lives of ordinary Papua New Guineans, one finds no sharp increase in accusations of witchcraft- and sorcery-related violence. There have always been such accusations - perhaps social media has made them more visible. There is, however, an increase in brutal violence inflicted on the accused, and only in particular parts of the country. Absent too, from popular discourse, is a balanced approach that would also acknowledge the negative effects of Eurocentric modernity and its contemporary guise of development, and consideration of its impact upon civil unrest and criminal activity, and indeed upon gender violence. For example, while recognising that violence has been prevalent in gender relations in much of PNG since before colonisation, recent scholarship presented in Engendering Violence in Papua New Guinea (Jolly et al. 2012) also explores the links between modernity and gender violence, exposing the culpability of commodity economics and extractive industries as well as the introduction of Western justice and law.

Hau' ofa (1994) has written eloquently on colonial, postcolonial and neo-colonial Eurocentric relations of control, domination and subordination in Oceania. He too is cognisant that the international system, its norms and institutions, is one in which Pacific islanders have been forced to participate. It is not of our making and rarely reflects our cultural values of rights embedded in responsibilities (Hau'ofa 1994). (I should make clear that Hau'ofa does not speak of rights embedded in responsibilities. It has been argued that the more common perspective advanced by indigenous Pacific island scholars is that the concept of human rights does not inform our cultures. ${ }^{17}$ I agree that direct comparison between the West and Melanesia, for example, exposes a lack vis-à-vis the West.

16 For a critique of the discourse of development see Escobar (1995). The role of law in the construction of societies that lack is outlined in Nader (2004-2005).

17 See, for example, Dickson-Waiko (2001). 
However, when I situate myself in my culture, unconcerned with comparisons, I see that as a woman from a matrilineal society I have very clear rights, such as those regarding custodianship of land, but these rights are always embedded in responsibilities to my community. That they are not the same rights accorded by, and in, Western societies does not diminish that I do have rights in my society. It is for this reason that I speak of rights embedded within responsibilities.) Inspired by Hau'ofa, I am compelled to ask different questions - decolonial questions. For instance, in lieu of assuming that belief in witchcraft and sorcery is the cause of insecurity and fear, I ask too, what is it in the Eurocentric model of development that fuels this culture of insecurity and fear? Is it that it is a model that reinforces inequality and hierarchy and has reinforced patriarchy in many parts of PNG? Is it that it is a model that is predicated on individual rights without explicit corresponding responsibilities? ${ }^{18}$ Is it that it is a model that Melanesians have had no part in designing, let alone influencing, such that the outcome of trying to implement it is akin to forcing a square peg into a round hole?

Other questions I am compelled to ask include if witchcraft and sorcery are a problem, should we not be also talking about these practices in places outside Melanesia, for example, Wiccan practices across Europe and the United States? Moreover, if sorcery and witchcraft are a negative force on economic and social development, then what of demand-sharing and the obligation to reciprocity and exchange that underlies social relations in PNG? Should one regulate kinship as well in the name of economic development?

In a different vein, like Grosfoguel (2008:1) I also ask, '[h]ow can we overcome Eurocentric modernity without throwing away the best of [it] as many Third World fundamentalists do?' And, like other decolonialists, I argue that an epistemic pluralism that embraces majority world perspectives can progress this debate precisely because decoloniality respects the many multiples of local particularities. (I prefer 'majority world' to designate what is often referred to as the developing world, in order to avoid the infantilisation implicit in the term 'developing'.) Scott (1996:71), however, is correct to highlight that '[i]f the sharing of knowledge were to be reduced to a skimming-off by Western specialists of indigenous empirical insights, and their mere insertion into existing Western paradigms, then it would be an impoverished and failed exchange that would ultimately contribute to undermining indigenous societies and cultures'. Decoloniality, therefore, embraces the best of Eurocentric knowledge production and the best of majority world knowledge, acknowledging difference without needing to control and dominate it.

18 I acknowledge that human rights discourse does emphasise responsibilities through the critique of neo-liberalism. The responsibilities that I focus on in Melanesian societies are actual lived responsibilities, to which we are socialised from birth, not an intellectual discourse. 
These reflections stem from both a matrilineal and decolonial perspective. But regardless of either perspective, without any evidence of a causal link between witchcraft/sorcery and the breakdown of civil society and social relations in Milne Bay, the real issue for me becomes violence, whatever its source. And it is from this perspective that I address policy and practical measures in the next section.

\section{Policy and practical measures}

I would now like to share some thoughts on policy and practical measures and I present these from my assumption that violence, indeed growing violence, is the issue that needs to be addressed.

Ume Wainetti, national coordinator of the PNG Family and Sexual Violence Action Committee, gave a talk at The Australian National University shortly before the June 2013 conference Sorcery- and Witchcraft-Related Killings in Melanesia. Three points resonated. Firstly, a trip she had taken to the United States to learn about services that are provided to those who have suffered from family and sexual violence was, in her words, a waste of time. Not because the services were deficient but because PNG cannot hope to replicate that level or type of service in the near to medium-term; in other words, context is critical. Secondly, Ume spoke of how a basic understanding of human rights and the operation of the rule of law had enabled at least one woman in the highlands to break a cycle of violent payback through the use of court orders in lieu of tribal war. And thirdly, Ume has observed that younger Papua New Guineans understand their rights but that these rights are exercised in a vacuum free of responsibility. I shall address these points collectively.

Research on human rights and gender violence reveals that vernacularisation of human rights is necessary for local acceptance, for without context many will resist the fundamentalist insistence that rights can only be framed in one way (Merry 2006). Translation, however, does not lead to transformation. At the local level a rights framework will coexist with other moral frameworks, contingency dictating which framework will be leveraged by individuals, predicated to a large extent on which system is perceived to best deliver the desired outcomes. For example, a battered woman in the highlands of PNG, despite being aware of her human rights, may elect customary justice if she perceives it to be the system that will best deliver her the desired outcomes for that situation. While the paradox of contextualising the universal presents a number of dilemmas, it does enable incremental change, which can be more sustainable, at a local level. My experience as a board member for an international non-government organisation confirms this: WASH (water, sanitation and hygiene) messages are 
best crafted and delivered by locals in order to be taken seriously and integrated into the lives of households and communities. Another example is that of Tostan, a non-government organisation working in Senegal to give women a say in female genital cutting practices, which are illegal in Senegal. By engaging the community in debating moral frameworks of rights and responsibilities, communities are able to make their own collective decision about the practice.

Advocacy for human rights education must not only be framed in local terms - it needs to be explicit about the corollary of rights, which is responsibility. A fundamental issue in PNG over the discourse of human rights is the conflict between individual rights and collective responsibilities (Dickson-Waiko 2001). Milne Bay scholar Dickson-Waiko, questioning the ethics of insistence on individualism, informs us that in PNG the collective, by way of community and/or kinship relations, is so critical to the well-being of the human that if the appropriate relationships are not maintained the community itself may be destroyed and with it the individual members' (Dickson-Waiko 2001:51). The idea of the human, therefore, cannot be separated from the idea of the community.

Yet to make the argument, either for vernacularisation, or for the importance of the collective, often invites charges of relativism with the corresponding charge that this stance encourages female subordination in particular, and repression in general (Jolly 1996). However, both Jolly and Dickson-Waiko (2003) have demonstrated that women of Vanuatu and PNG, far from being trapped in rigid traditions, are proactive in debating and defining their contemporary rights visà-vis culture, modernisation, religion and the state. Indeed, this was evident as well at the June 2013 conference, whereby PNG activists Lily BeSoer and Clara Bal demonstrated through their work that patriarchal traditions of violence can be challenged without destroying the ontological Papua New Guinean human, embedded in social relations. It has also been evident in the way ordinary Papua New Guineans have participated in public events and on social media to protest against the violence that also motivated this conference. In the PNG context then, rights and responsibilities are equally important and Papua New Guineans are aware of the tensions that these generate and are actively negotiating the pressures.

\section{Culture? Modernisation? Both?}

I started with some words about culture and I will finish with the same.

Many people from the developing world, or the majority world as I prefer to call it, can tell you that there is considerable trauma in having one's culture or aspects of it essentialised as inferior and primitive, as the media reports 
have tended to do when reporting on witchcraft- and sorcery-related violence in PNG. We joke about it among ourselves but I suspect that the mainstream development model that demonises our cultures by constructing the idea that we are lacking morally and intellectually, actually creates many of the social tensions that plague PNG. ${ }^{19}$ The adoption of aspects of Eurocentric modernity brings its own traumas but the process would be much less painful without the implicit racial and cultural hierarchies built into it.

We all know intuitively that any process of change brings its own stresses, whether a divorce at the household level or new technology at the organisational level. In fact, in my experience in international business, large, blue chip corporations would rarely undertake programs of change without giving due consideration to how the trauma of displacing one organisational culture for another is likely to unfold. There is recognition in the world of international business that cultural disruption can create fundamental organisational instability and that this is not a healthy situation over the long term. This acknowledgement is largely absent from mainstream development, although critiques from some scholars and practitioners have noted the lack of reflexivity in the model that rarely questions the racial and cultural hierarchies that are implicit within it. ${ }^{20}$

Back in 1996 Nader (1996b:7) noted that indigenous peoples were becoming much better informed, and a decade later Maori scholar Linda Tuhiwai Smith (2004:34) wrote 'we are still being colonized (and know it)'. What this means is that majority world peoples are cognisant of the myth of the white man's burden of refashioning the uncivilised rest, critiqued recently by Nader (2007) and Easterly (2006), and which underpins top-down development. To consider this myth from the bottom up is to identify another myth - that the rest desire to be like the West. The reality, however, is that some things are adopted (washing machines, air travel), others not (discarding customary land tenure), and yet others are adapted to local needs (Christianity). In fact, majority world peoples have always been aware of racial and cultural hierarchies, but are becoming less accepting, as Nader notes. Policymaking and implementation surrounding cultural issues such as witchcraft and sorcery, and introduced institutions such as rule of law and human rights also have to negotiate this terrain. Indeed, there are a growing number of us in the majority world for whom postcolonial rhetoric has done little to shift power relations between a minority world of developed nations and a majority world of emerging and developing states. This is leading us to adopt a decolonial stance that calls for expression of human rights through recognition that our peoples and cultures had, and continue to have, moral frameworks. And that it is by leveraging our own cultural models

19 While this is not the conclusion of this volume, it nonetheless touches on aspects of modernisation that impact upon gender violence (Jolly et al. 2012).

20 See, for example, Escobar (1995). 
that, yes, include beliefs in what the West calls witchcraft and sorcery, in lieu of having foreign models imposed on us, which will enable us to better negotiate the transition to modernity on our terms. Only through this can we live up to Hau'ofa's exhortation that '[w]e must not allow anyone to belittle us again and take away our freedom' (Hau'ofa 1994:160).

Witchcraft and sorcery form part of the cultural terrain and indigenous knowledges of PNG. But culture is not a valid argument for the use of violence. Nor is violence a valid argument for the outright and totalitarian dismissal of all aspects of PNG cultures. If indeed violence were a valid argument for such, then what of Eurocentric modernisation, which from conquest to colonisation and Christianisation, through to globalisation and developmentalism, has been a project of organised violence through enslavement, genocide and territorial appropriation, and which continues to unfold as structural and epistemic violence in the international system ${ }^{21}$ The fact is that for most Papua New Guineans it is not, and never will be, either culture or modernisation. It is culture and modernisation. A linear approach to policymaking assumes that increasing modernisation will result in dissolution of cultural bonds. A nonlinear approach, however, rejects the paradigm of (A OR B) or (A therefore B) to replace it with the paradigm of both (A AND B). This approach is crucial for the complexity, diversity and dynamism of a nation-state like PNG.

\section{Conclusion}

I have argued that a large part of the knowledges dismissed as witchcraft and sorcery constitute an aspect of both the cultural heritage and knowledge capital of PNG, and that in Milne Bay, this knowledge is highly correlated with gender egalitarianism. In fact, the paradox that Milne Bay presents - highly articulated forms of witchcraft and sorcery yet low levels of gender violence - suggests that factors beyond witchcraft and sorcery inform a large part of the brutal violence that has been directed at those accused in other parts of PNG. I have suggested that by approaching the issue from a decolonial perspective one is able to frame different questions to explore contributing factors to this violence. On the issue of policy, I have argued that the starting point be the lives and actions of ordinary people, rather than international and state rhetoric.

The late Epeli Hau'ofa had great faith in the ability and resilience of Pacific island peoples to adapt, saying ' $[\mathrm{t}]$ he future lies in the hands of our own people, not of those who would prescribe for us, get us forever dependent and indebted because they can see no way out' (Hau'ofa 1994:159). For we Melanesians, it

21 For elaboration see Dussel (2000), Maldonado-Torres (2004), Mignolo (1995), and Quijano and Ennis (2000). 
is necessary that we take responsibility for effecting the changes that provide for our contextual development. There are no easy answers. In the spirit of generating solutions that are appropriate for us, there needs to be more intraMelanesian, indeed intra-Oceanic, debate that is driven by agendas we set. And we should be engaging more with others in the global south, with whom we share more than the experience of being colonised. We place similar value in our kinship systems and we may find that we are also more united in the concept of both rights and responsibilities than we are in the concept of just individual rights. ${ }^{22}$ Like Hau'ofa, I am optimistic that our peoples, having thrived for millennia before European contact, and despite colonisation, continue to have the ability and resilience to negotiate change.

\section{Acknowledgements}

I am grateful for feedback received from Anne Dickson-Waiko, Katherine Lepani, Katerina Teaiwa and Margaret Jolly.

\section{References}

Demian, M. 2000. Longing for Completion: Toward an Aesthetics of Work in Suau. Oceania 71(2):94-109.

Demian, M. 2007. 'Land Doesn't Come from Your Mother, She Didn't Make It with Her Hands': Challenging Matriliny in Papua New Guinea. In H. Lim and A. Bottomley (eds.) Feminist Perspectives on Land Law. London: RoutledgeCavendish, 155-70.

Dickson-Waiko, A. 2001. Women, Individual Human Rights, Community Rights: Tensions within the Papua New Guinea State. In P. Grimshaw, K. Holmes and M. Lake (eds.) Women's Rights and Human Rights: International Historical Perspectives. Basingstoke: Palgrave, 49-70.

Dickson-Waiko, A. 2003. The Missing Rib: Mobilizing Church Women for Change in Papua New Guinea. Oceania 74(1/2):98-119.

Dobell, G. 2007. The 'Arc of Instability': The History of an Idea. In R. Huisken and M. Thatcher (eds.) History as Policy: Framing the Debate on the Future of Australia's Defence Policy. Canberra: ANU E Press, 85-104.

22 In many African societies, kinship is an important organising principle (see Oyěwùmí 1997). 
Dussel, E.D. 2000. Europe, Modernity, and Eurocentrism [translated by J. Krauel and V.C. Tuma]. Nepantla: Views from South 1(3):465-78.

Easterly, W.R. 2006. The White Man's Burden: Why the West's Efforts to Aid the Rest Have Done So Much Ill and So Little Good. New York: Penguin Press.

Escobar, A. 1995. Encountering Development: The Making and Unmaking of the Third World. Princeton, NJ: Princeton University Press.

Grosfoguel, R. 2008. Transmodernity, Border Thinking, and Global Coloniality: Decolonizing Political Economy and Postcolonial Studies. Eurozine [online]. http://www.eurozine.com/pdf/2008-07-04-grosfoguel-en.pdf, viewed $17 / 6 / 2013$.

Hau'ofa, E. 1994. Our Sea of Islands. The Contemporary Pacific 6(1):147-61.

Jolly, M. 1996. Woman Ikat Raet Long Human Raet O No? Women's Rights, Human Rights and Domestic Violence in Vanuatu. Feminist Review 52(Spring):169-90.

Jolly, M., C. Stewart and C. Brewer 2012. Engendering Violence in Papua New Guinea. Canberra: ANU E Press.

Kaniku, A. 1981. Milne Bay Women. In D. Denoon and R. Lacey (eds.) Oral Tradition in Melanesia. Port Moresby: University of Papua New Guinea and Institute of Papua New Guinea Studies, 188-203.

Lawrence, S.E.-L. 2013. Gender and Development in Papua New Guinea: Matriliny and Indigenous Best Practice in Gender Relations. Masters thesis. Deakin University, Geelong, Australia.

Lepani, K. 2012. Islands of Love, Islands of Risk: Culture and HIV in the Trobriands. Nashville: Vanderbuilt University Press.

Lepowsky, M.A. 1993. Fruit of the Motherland: Gender in an Egalitarian Society. New York: Columbia University Press.

Macintyre, M. 1983. Changing Paths: An Historical Ethnography of the Traders of Tubetube. PhD thesis, The Australian National University, Canberra.

Macintyre, M. 1987. Flying Witches and Leaping Warriors: Supernatural Origins of Power and Matrilineal Authority in Tubetube Society. In M. Strathern (ed.) Dealing With Inequality: Analysing Gender Relations in Melanesia and Beyond. Cambridge and New York: Cambridge University Press, 207-28.

Macintyre, M. 1995. Violent Bodies and Vicious Exchanges: Personification and Objectification in the Massim. Social Analysis 37:29-43. 
Talking it Through

Maldonado-Torres, N. 2004. The Topology of Being and the Geopolitics of Knowledge. City 8(1):29-56.

Merry, S.E. 2006. Human Rights and Gender Violence: Translating International Law into Local Justice. Chicago: University of Chicago Press.

Mignolo, W. 1995. The Darker Side of the Renaissance: Literacy, Territoriality, and Colonization. Ann Arbor: University of Michigan Press.

Murray, H. 1912. Papua or British New Guinea. London: T. Fisher Unwin.

Nader, L. 1996a. Naked Science: Anthropological Inquiry into Boundaries, Power, and Knowledge. New York and London: Routledge.

Nader, L. 1996b. Introduction: Anthropological Inquiry into Boundaries, Power, and Knowledge. In L. Nader (ed.) Naked Science: Anthropological Inquiry into Boundaries, Power, and Knowledge. New York and London: Routledge, 1-25.

Nader, L. 2004-2005. Law and the Theory of Lack. Hastings International and Comparative Law Review 28(2):191-204.

Nader, L. 2007. Promise or Plunder? A Past and Future Look at Law and Development. Global Jurist 7(2). doi: 10.2202/1934-2640.1221.

Oyĕwùmí, O.É. 1997. The Invention of Women: Making an African Sense of Western Gender Discourses. Minneapolis: University of Minnesota Press.

Patterson, M. 1974. Sorcery and Witchcraft in Melanesia. Oceania XLV(2): 132-60.

Quijano, A. and T.B.M. Ennis 2000. Coloniality of Power, Eurocentrism, and Latin America. Nepantla: Views from South 1(3):533-80.

Rosewarne, S. 1997. Australia's Changing Role in the South Pacific: Global Restructuring and the Assertion of Metropolitan State Authority. Journal of Australian Political Economy 40(Dec):80-116.

Rumley, D. 2006. Australia's Arc of Instability: Evolution, Causes and Policy Dilemmas. The Otemon Journal of Australian Studies 32:37-59.

Sanday, P.R. 1981. Female Power and Male Dominance: On the Origins of Sexual Inequality. Cambridge: Cambridge University Press.

Scott, C. 1996. Science for the West, Myth for the Rest? The Case of James Bay Cree Knowledge Construction. In L. Nader (ed.) Naked Science: Anthropological Inquiry into Boundaries, Power, and Knowledge. New York and London: Routledge, 69-86. 
Smith, L.T. 2004. Decolonizing Methodologies: Research and Indigenous Peoples. London and New York: Zed Books.

Tambiah, S.J. 1990. Magic, Science, Religion, and the Scope of Rationality. Cambridge: Cambridge University Press.

UNESCO 2005. Convention on the Protection and Promotion of the Diversity of Cultural Expressions 2005. UNESCO. http://portal.unesco.org/en/ev.phpURL_ID=31038\&URL_DO=DO_TOPIC\&URL_SECTION=201.html, viewed $3 / 6 / 2013$.

UNESCO 2006. Traditional Knowledge. UNESCO Bureau of Public Information. http://www.unesco.org/bpi/pdf/memobpi48_tradknowledge_en.pdf, viewed 3/6/2013.

Wetherell, D. 2012. Creating an Indigenous Christian Leadership in Papua. The Journal of Pacific History 47(2):163-85.

Wetherell, D. and C.W. Abel 1998. First Contact Mission Narratives from Eastern Papua New Guinea. The Journal of Pacific History 33(1):111-16. 
This text is taken from Talking it Through: Responses to Sorcery and Witchcraft Beliefs and Practices in Melanesia, edited by Miranda Forsyth and Richard Eves, published 2015 by ANU Press, The Australian National University, Canberra, Australia. 